\title{
Countermeasures for the Development of Tourism Products with Historical and Cultural Features in Harbin
}

\author{
Jifeng Chang ${ }^{1}$, Xiaojun Lu ${ }^{1, *}$ \\ ${ }^{1}$ Harbin University of Commerce, 150028, China \\ ${ }^{2, *}$ Harbin University of Commerce, 150028, China
}

Keywords: Historical culture; Tourist products; Countermeasures for the Development

\begin{abstract}
Due to the special geographical location and complex recent historical development, Harbin has created its own unique cultural context and diverse cultural integration. More than 100 historical cultures such as Jinyuan culture, black soil culture, red revolutionary culture and immigration culture constitute the main body of history and culture in our city. We have to deeply excavate and integrate the unique historical and cultural resources of the city, constantly advance it with the times and expand the historical and cultural connotation. And we have to integrate the historical and cultural characteristics into the tourism industry, exhibition industry and other related industries to further promote the development of culture. Through promoting the development of historical cultural tourism, it will make the tourism industry an important economic growth point of the city and provide strong support for the realization of the strategic goal of a strong cultural province. The research of this paper is highly compatible with the spiritual requirements of the central government. It is also an important channel to accelerate the implementation of the new strategy of the city and strive to achieve the grand goal of the international modern metropolis. It has important practical value and guiding significance.
\end{abstract}

\section{哈尔滨市历史文化特色旅游产品开发对策}

\author{
常纪锋 ${ }^{1}$, 鲁啸军 ${ }^{2, *}$ \\ 1哈尔滨商业大学, 哈尔滨 150028 \\ 2哈尔滨商业大学，哈尔滨 150028
}

关键词: 历史文化; 旅游产品; 开发对策

摘要：哈尔滨由于特殊的地理区位和复杂的近代历史发展情况的缘故, 生成了自己独特的文 化脉络和多元的文化交融现象，金源文化、黑土文化、红色革命文化和移民文化等 100 多处 历史文化资源构成了我市历史文化主体。深度挖掘和整合我市独有的历史文化资源, 不断与 时俱进拓展城市历史文化内涵，将历史文化特色结合贯穿到旅游产业、会展业等相关产业之 中, 进一步促进文化大发展, 通过促进历史文化旅游的发展, 使旅游产业成为我市重要的经 济增长点, 为实现文化强省的战略目标提供有力支撑。本文的研究高度契合中央的精神要求, 更是加速我市新战略实施, 努力实现国际现代大都市宏伟目标的重要渠道, 具有重要的现实 价值和实践指导意义。

\section{1. 国内外研究现状}

国外对文化旅游的研究开始较早，且取得了诸多研究成果。文化旅游就是那些包括语言、 音乐、艺术、旅游目的地的感受、手工艺、建筑、古迹、遗产遗迹、宗教、技术、教育等相 关联的旅游活动 (Jamieson, 1994)。这类文化旅游吸引的不仅是大众游客还涵盖了专项旅游 者, 有利于促进旅游地发展（西尔布伯格, 1994 和赫伯特, 1996)。互动性在文化创意旅游 
的发展中十分重要 (Crisp Raymond, 2000 和麦克切尔和克罗斯, 2006 ), 具有不可替代性, 同时, 科学技术的植入对于传统旅游业的巨大影响 ( Vermeulen, 2005 和格雷格·理查兹, 2006 以及沃尔、马西森，2007)，公共部门作为文化主导再生的角色作用 (OndřejSlach，2012)。 传统食品是理解社会文化的重要组成部分, 也是文化表达的重要媒介, 可以有效地瞄准和开 拓旅游市场 (Francis Eric, 2013)。通过将地理学引入餐馆领域, 更好地掌握了旅游质量的地 理位置（WidedBatat， 2014 和 Pieter Terhorst，2015），以便更好地服务于整个旅游市场。

哈尔滨市被评为全国历史文化名城已二十余年，“历史文化名城”和历史文化的概念还不是 太深入人心，优势还没有得到充分的发挥 (尹宏峰, 2016)。区域旅游同质化现象较为严重, 市场竞争日益激烈。哈尔滨旅游行业若要得到可持续发展, 就必须要不断开发新型文化旅游 资源（李雪，2016）。以观光为主的传统旅游模式已经不能满足消费者的需求，应基于文化创 意视角, 结合旅游地的自身特点和资源优势进行深度开发 (王博, 2017 和徐艳红, 2017), 并且在历史文化街区景观改造与保护性设计开发时需要结合街区的具体环境进行整体开发、 综合治理（文峰，2017 和王天娇，2017）。

\section{2. 哈尔滨市历史文化特色旅游产品开发的实践价值}

哈尔滨市作为中国历史文化名城, 由于特殊的地理区位和复杂的近代历史发展情况的缘故, 生成了自己独特的文化脉络和多元的文化交融现象，金源文化、黑土文化、红色革命文化和 移民文化等 100 多处历史文化资源构成了我市历史文化主体。近年来，冰雪文化在我市蓬勃 发展, 蜚声海内外, 加之随着新战略实施, “湿地文化”也初具规模, “冰城夏都”旅游品牌得 到越来越多的人认可, 并且形成了一定影响力, 尽管旅游产业在我市经济产业结构中占有显 著的地位，但是得天独厚的历史文化资源还未得到有效的整合和利用。

哈尔滨作为东北地区的区域中心城市，担负着振兴东北“领头羊”的重任，挖掘和整合我市 独有的历史文化资源, 不断与时俱进拓展城市历史文化内涵, 将历史文化特色结合贯穿到旅 游产业、会展业等相关产业之中，进一步促进文化大发展，通过促进历史文化旅游的发展， 使旅游产业成为我市重要的经济增长点, 旅游业成为我市国民经济中的战略支柱性产业地位, 为实现文化强省的战略目标提供有力支撑。研究哈尔滨市历史文化特色旅游产品开发策略, 高度契合中央的精神要求, 更是加速我市新战略实施, 努力实现国际现代大都市宏伟目标的 重要渠道, 具有重要的现实价值和实践指导意义。

\section{3. 哈尔滨市历史文化特色旅游产品开发的意义}

通过研究哈尔滨市历史文化特色旅游产品开发, 作为一个切入点, 可以抓住新形势下旅游 发展机遇。哈尔滨作为“中蒙俄经济走廊”上的核心城市, 通过历史文化特色旅游产品的开发:

（1）有利于深入落实《中蒙俄经济走廊黑龙江陆海丝绸之路经济带建设规划》精神;

(2) 通过积极搭建国际旅游合作大平台, 可以为深化中俄旅游战略合作和东部陆海丝䀦 之路经济带建设提供重要支撑;

（3）可以通过历史文化特色旅游产品开发打造对俄全方位交流合作平台, 带动哈尔滨市 与日韩等其他国家和地区间的开放与合作，走向互联互通、文化融合、品牌合作、资源共享 的新阶段;

（4）有利于借助国家《关于促进旅游业改革发展的若干意见》《关于加快转变农业发展方 式的意见》《关于进一步促进旅游投资和消费的若干意见》三大政策持续发力开启旅游发展新 篇章。

\section{4. 哈尔滨市历史文化特色旅游产品开发基本思路}

哈尔滨市作为国际性的旅游城市, 随着城市建设的快速发展以及对环境保护的日趋关注, 人们逐渐意识到历史文化特色旅游产品开发的重要性。在此背景下，本文以可持续发展的视 
角重新审视有关历史文化特色旅游产品开发议题, 并以哈尔滨市历史文化特色旅游产品开发 为研究对象, 分析哈尔滨市历史文化特色旅游产品开发的现状, 打造“五位一体”的哈尔滨市 历史文化特色旅游产品开发体系, 并提出相应的哈尔滨市历史文化特色旅游产品开发策略的 实施与保障方案, 从而为进一步哈尔滨市历史文化特色旅游产品开发的推进提供了切实的路 径选择。

\section{5. 哈尔滨市历史文化特色旅游产品开发策略}

（1）整合、构建哈尔滨市历史文化旅游吸引物体系, 且在既有的旅游特色和品牌基础上, 增加和强化历史文化特色元素。哈尔滨现有的旅游资源相对全面, 金源文化旅游、对俄旅游、 红色文化游、生态度假游、森林小火车漫游、美丽乡村游等一系列项目虽然包含了历史文化 的内涵, 为哈尔滨的经济做出了显著的贡献, 但区域性特点非常明显, 同质化严重, 历史文 化特点并不突出, 整合、构建哈尔滨市历史文化旅游吸引物体系, 且在既有的旅游特色和品 牌基础上, 增加和强化哈尔滨的金源文化、黑土文化、红色文化等历史文化特色元素, 为首 要内容。

(2) 建设哈尔滨市旅游市场开发与营销体系、打造文化特色旅游品牌。实施哈尔滨全域 旅游营销策略, 以历史文化特点为主线, 实现区域间的无缝对接和联合行动, 要避免各地趋 同式营销，做好联合推介和差异化推介，互为平台，共同唱戏，实现网站互联、客源互荐、 信息共享、用户流量互通。重点提升和凸显哈尔滨历史文化特点, 使哈尔滨市“冰雪、文化、 生态、时尚”四大旅游品牌得到公众的广泛认知, 并获得较高的美誉度。

（3）融合哈尔滨历史文化特色, 提质哈尔滨市公共服务体系建设。以提升旅游公共服务 体系建设水平为突破口, 在现有公共服务平台基础上, 强化历史文化特色在旅游各要素上的 融合, 从而提升哈尔滨建设全域化、智慧化、平台化、市场化的旅游公共服务体系, 突出供 给侧结构性改革, 统筹全域要素配置, 提升旅游服务水平与标准, 提供为全民服务的旅游公 共服务体系。

(4) 建立哈尔滨市“文化旅游+”产业系统。哈尔滨旅游业的发展正在从封闭的旅游自循环 向开放的“旅游”融合发展方式转变, 充实和加强以历史文化特色旅游与装备制造业、教育培 训业、创意产业、智慧产业等产业的融合力度, 旨在从旅游企业单打独享到社会共建共享转 变, 充分调动各方发展旅游的积极性, 以旅游为导向整合资源, 形成综合产业综合抓的局面, 实现从“小旅游”格局向“大旅游”格局转变, 形成全行业旅游新产能。

（5）搭建哈尔滨市全域旅游支撑体系与平台。建设本地化旅游服务平台, 整合国际、技 术、金融、创业等平台力量, 结合全域旅游资源, 推动各类务实高效、互惠互利的旅游合作, 以全面带动旅游产业的发展壮大, 推进旅游业向更高层次转型升级。

（6）建立健全哈尔滨市历史文化特色旅游产品开发实施与保障体系。通过建立旅游发展 联席会议、试点旅游部门一体化管理体制、建立健全行业协会来全面推进旅游管理体制改革; 通过拓展旅游资金融资渠道、成立旅游投、融资公司、设立旅游产业发展基金来建立旅游发 展资金保障体系; 通过修订完善旅游服务条例法规、建立和引入旅游专项标准体系、强化执 法力度和投诉体系建设来发布旅游法律, 保障哈尔滨市历史文化特色旅游产品开发健康发展; 通过建立完善教育与培训体系、加强优秀旅游人才引进、组建旅游专家智能库来加强旅游专 业人才队伍建设。

\section{致谢}

本项目由 2018 年度黑龙江省经济社会发展重点研究课题项目 (课题名称: 哈尔滨市历史 文化特旅游产品开发策略研究) 资助。 


\section{[参考文献]}

[1] Attractions [J]. Journal of Sustainable Tourism, 2006, 14 (5):473-488.

[2] OndřejSlach; TomášBoruta, What Can Cultural and Creative Industries Do for Urban Development? [J], 2012(4)

[3] Francis Eric,Traditional food preferences of tourists in Ghana[J]. Amuquandoh, British Food Journal . 2013 (7)

[4] WidedBatat ,Towards viral systems thinking: a cross-cultural study of sustainable tourism ads[J] . Sonja Prentovic.Kybernetes . 2014 (3)

[5] Pieter Terhorst, Urban tourism and spatial segmentation in the field of restaurants: the case of Amsterdam[J], Pieter Terhorst,HilalErku-ztürk. International Journal of Culture, Tourism and Hospitality Research . 2015 (2)

[6] 尹海洁, 王雪洋.城市历史街区发行中的“文化之歾”一一以哈尔滨市道外历史街区为例 [J]. 现代城市研究. 2014（6）

[7] 马文婷.哈尔滨市道外历史文化街区的保护与旅游开发[D]. 2014（3）

[8] 杨圆圆, 徐秋华, 苏金豹.哈尔滨市湿地旅游市场分析及战略规划研究 [J]. 安徽农业科 学.2014 (7)

[9] 彭巍.哈尔滨历史文化旅游街区开发探讨[J].边疆经济与文化. 2015（5）

[10] 吕淳.哈尔滨市文化公园旅游规划设计分析[D]. 2015（6）

[11] 李雪.哈尔滨犹太旅游文化资源的开发及前景 $[\mathrm{J}]$. 卷宗. 2016（11）

[12] 尹宏峰.发挥历史文化名城优势 打造哈尔滨文化强市[J].决策与信息 (中旬刊).2016(11)

[13] 王博.基于文化创意视角的哈尔滨旅游尝试开发研究[D]. 2017（1）

[14] 文峰.历史文化街区景观改造与保护性设计探究——以哈尔滨市中华巴洛克历史文化街 区为例 $[\mathrm{J}]$.艺术教育. 2017（3）

[15] 徐艳红.基于文化创意视角的哈尔滨文化旅游发展研究[D].2017（5）

[16] 王阳，张金金.黑龙江省红色边疆农场民俗旅游资源开发对策研究[J].经济研究.2017（7）

[17] 王天娇, 杨圣玥, 肖紫嫣.城市历史文化街区保护与旅游开发策略研究——以哈尔滨市道 外区中华巴洛克街区为例[J].青春岁月. 2017（12）

[18] 王红丽.哈尔滨市双城区历史文化旅游资源的开发策略[J].学理论. 2017（2） 